\title{
Rapid Nestling Mortality in Arctic Peregrine Falcons Due to the Biting Effects of Black Flies
}

\author{
Alastair Franke, ${ }^{1}$ Vincent Lamarre ${ }^{2}$ and Erik Hedlin ${ }^{3}$
}

(Received 27 March 2016; accepted in revised form 11 May 2016)

\begin{abstract}
This note describes nestling mortality in Arctic Peregrine Falcons (Falco peregrinus tundrius) due to the biting effects of blood-feeding black flies (Diptera: Simuliidae). At a nest site near Rankin Inlet, Nunavut, Canada $\left(62^{\circ} 49^{\prime} \mathrm{N}\right.$, $92^{\circ} 05^{\prime} \mathrm{W}$ ), a brood of four nestlings died on 20 July 2013 from the direct effects of severe bites attributed to black flies. Within three hours of the onset of blood-feeding, black flies had caused widespread, uniformly distributed hemorrhagic coalescent lesions over the head and body of all nestlings. Approximately seven hours after the first flies appeared, the female falcon removed the carcasses of the dead nestlings from the nest. Nestlings at eight additional sites also suffered the effects of biting black flies in 2013, resulting in the deaths of 13 of 35 nestlings. A less pronounced outbreak also occurred in 2012 and resulted in the deaths of seven nestlings at four sites. No nestling mortality due to black flies has been documented in any other year from 1982 through 2015. To our knowledge, these observations document the northernmost lethal attack by ornithophilic black flies in North America.
\end{abstract}

Key words: Arctic; avian; climate change; black fly; mortality; Peregrine Falcon; Simuliidae

RÉSUMÉ. Cet article décrit des événements de mortalité d'oisillons chez le faucon pèlerin (Falco peregrinus tundrius) causés par des morsures de mouches noires hématophages (Diptera : Simuliidae). À un site de nidification près de Rankin Inlet, Nunavut, Canada ( $\left.62^{\circ} 49^{\prime} \mathrm{N}, 92^{\circ} 05^{\prime} \mathrm{O}\right)$, les quatre oisillons d'une couvée sont morts le 20 juillet 2013 des effets directs de morsures sévères attribuables aux mouches noires. Dans les trois heures suivant le début de l'activité des hématophages, les mouches noires avaient causé des lésions hémorragiques et coalescentes uniformément distribuées sur la tête et le corps des oisillons. Environ sept heures après l'apparition des premières mouches, la femelle a retiré les carcasses des oisillons morts du nid. Des oisillons à huit autres sites de nidification ont également subi les effets des mouches noires hématophages en 2013, entraînant la mortalité de 13 oisillons sur un total de 35. Une émergence moins prononcée s'est aussi produite en 2012 et a causé la mort de sept oisillons à quatre sites de nidification. Aucune mortalité d'oisillons causée par les mouches noires n'a été documentée de 1982 à 2015. À notre connaissance, ces observations documentent les attaques létales par les mouches noires ornithophiles les plus nordiques en Amérique du Nord.

Mots clés : Arctique; aviaire; changement climatique; mouche noire; mortalité; faucon pèlerin; Simuliidae

\section{INTRODUCTION}

Black flies (Diptera: Simuliidae) are ectoparasitic insects found where running water is available for egg laying and larval development (Currie and Hunter, 2008). Some species of black fly use nutrients acquired during the larval stage for egg development, but most require a blood meal prior to producing and laying eggs. Blood-feeding black flies typically feed on the blood of mammals or birds, or both (Currie and Hunter, 2008).

Black fly attacks have been documented in domestic animals (Adler et al., 2004) and wildlife (Currie and Hunter, 2008). Their effects are usually characterized by increased vascularization, edema, subcutaneous hemorrhage, tissue necrosis, and inflammation (Hunter et al., 1997). In wellfeathered birds, hemorrhagic lesions are generally limited to regions of the body where feathers are absent, including the eyelids, cere, corner of the beak, neck, underwings, and auricular openings (Fitch et al., 1946; Hunter et al., 1997; Smith et al., 1998). Fitch et al. (1946) attributed the death of Red-tailed Hawk (Buteo jamaicensis) nestlings four to eight days old to black flies and reported that affected nestlings modified their behaviour by repeated wing flapping and working their legs up and down, presumably in response to being bitten or in an attempt to avoid being bitten. In Wyoming, Smith et al. (1998) reported that a black fly infestation caused premature fledging, mortality, or both in Red-tailed Hawk nestlings (3-20 days old) through the cumulative effects of loss of blood and other body fluids. During a fouryear study in the Yukon, Doyle (2000) reported nest failure at nests with high counts of black flies ( $\geq 70$ flies) and suggested that death of nestlings $(\leq 20$ days old) occurred

\footnotetext{
${ }^{1}$ Arctic Raptor Project, Box 626, Rankin Inlet, Nunavut X0C 0G0, Canada; alastair.franke@ualberta.ca

${ }^{2}$ Département de biologie et Centre d'études nordiques, Université du Québec à Rimouski, 300 Allée des Ursulines, Rimouski, Québec G5L 3A1, Canada

${ }^{3}$ Department of Renewable Resources, University of Alberta, 751 General Services Building, Edmonton, Alberta T6G 2H1, Canada

(c) The Arctic Institute of North America
} 
rapidly since nestlings showed no evidence of weight loss between nest visits. In the same region, black flies were cited as the cause of death in 13 of 28 juvenile Great Horned Owls (Bubo virginianus) (Hunter et al., 1997).

Although nestlings in first or second down plumage are particularly vulnerable, adult birds can also be affected. In the Kluane Lake region (Yukon, Canada), roost site selection of alpine-breeding Great Horned Owls varied with black fly activity (Rohner et al., 2000). Owls switched from perches at mid-canopy level, where black fly activity was intense, to low-level roost sites (near the ground) in exposed open areas. Bukaciński and Bukacińska (2000) found reduced levels of parental care and increased nest desertion in Common Gulls (Larus canus) during years of black fly infestation. Solheim et al. (2013) reported severe morbidity in incubating adult female Snowy Owls (Bubo scandiacus) that would likely have died without veterinary intervention.

The effects of black flies on birds breeding at high latitudes have been reported previously (Doyle, 2000; Solheim et al., 2013), including the collection of Metacnephia bilineata (as Metacnephia saileri) from immature domestic geese in Kuujjuaq, Quebec, on the southernmost fringe of the Arctic ecoclimatic zone (cf. Adler et al., 2004:304-305). The present study documents the northernmost observation of ornithophily yet reported in North America, as well as the first observations of nestling mortality due to biting black flies in the Arctic Peregrine Falcon (Falco peregrinus tundrius).

A dense population of Peregrine Falcons breeding near the hamlet of Rankin Inlet, Nunavut, Canada $\left(62^{\circ} 49^{\prime} \mathrm{N}\right.$, $92^{\circ} 05^{\prime} \mathrm{W}$ ), has been intensively monitored since 1982 (Court et al., 1988a, b, 1990; Johnstone et al., 1996; Bradley et al., 1997; Franke et al., 2010, 2011, 2013; Anctil and Franke, 2013; L'Hérault et al., 2013; Anctil et al., 2014). Terminology used in describing nesting activities of Peregrine Falcons and a general description of the vegetation, climate, and geology of the study area are reported elsewhere (Court et al., 1988a, b). Within the study area, the Meliadine and Diane Rivers, as well as numerous lakes and ponds interconnected by streams, offer suitable reproductive habitat for black flies.

Since 2007, nest sites have been monitored using motion-sensitive cameras (RECONYX models, PC85 and PC800 Hyperfire) deployed at a distance of 1-2 $\mathrm{m}$ from the nest bowl. Images are used to document breeding phenology (e.g., lay date, hatch date), breeding behavior (e.g., feeding rate), and causes of mortality (e.g., rain, starvation, and predation). Cameras were programmed to capture one image immediately when triggered by motion, after which they remained insensitive to motion for three seconds. In addition, cameras were programmed to collect a single time-lapse image every 15 minutes. Memory cards and batteries were replaced every 5-10 days for the duration of the breeding season or until the site failed. During the 2013 breeding season, cameras were placed at 10 nest sites.

\section{DESCRIPTION OF OBSERVATIONS}

Two marked adult Peregrine Falcons, a female and a male, were observed on 24 May 2013 at a regularly monitored nest site. The pair subsequently produced and hatched four eggs; two hatched on 12 July 2013 and two on 13 July 2013. The nestlings were weighed on 19 July 2013 at approximately seven days of age; the smallest weighed $125 \mathrm{~g}$, and the largest, $173 \mathrm{~g}$. Nestlings were covered primarily by first down plumage, but second down had begun to emerge in all nestlings. Development of the nestlings was consistent with normal growth curves reported for this population (Court et al., 1988b). A rain gauge situated on the nest ledge indicated very low rainfall, recording zero rainfall for 26 June through 8 July 2013 and $0.4 \mathrm{~mm}$ rainfall for 9 through 19 July 2013. At the next site visit, on 26 July 2013, there were no nestlings on the nest ledge and neither adult was present.

Images recorded by the motion-sensitive camera indicated that all four nestlings had died on 20 July 2013 as a result of black fly bites. Prior to the onset of black fly feeding, all nestlings were brooded consistently. Camera images indicated that the nestlings were fed six times in the 12 hours preceding the appearance of black flies and that all four nestlings responded in a manner that would be consistent with normal feeding behavior (huddled together, sitting upright, actively soliciting and facing the female during feeding). Between feeding bouts, the nestlings were active on the nest ledge.

Relatively few $(<10)$ black flies were first observed on the brood of nestlings at 17:15 (Fig. 1). Although it is likely that other flies were buried within the down and were swarming about the nestlings, or otherwise out of view, over the next two hours images showed nestlings with clusters of four or five flies concentrated on the crown of each nestling's head, as well as four or five additional flies sitting on the back of each nestling. A hemorrhagic lesion was apparent on the back of one of the nestlings by 19:45, and two nestlings showed hemorrhagic lesions on the crown of their heads by 20:24 (Fig. 2). By 21:00, all four nestlings displayed widespread, uniformly distributed hemorrhagic lesions over the body and multiple coalescent head lesions. By 21:30, the body lesions were so numerous that they too had coalesced (Fig. 3). The attack was rapid and most intense over approximately 90 minutes between 20:00 and 21:30, during which the nestlings transitioned from appearing normal to exhibiting body-wide hemorrhagic lesions. The camera switched to infrared mode at approximately 22:22, and although the nestlings were alive, images showed that all four nestlings remained prostrate, with closed eyes, and were motionless for long periods (Fig. 4). The female falcon continued to brood the nestlings; however, by approximately 03:30 on 21 July 2013, the female had removed the carcass of one of the nestlings, and presumably cached it. Two more carcasses were removed by $03: 51$, and the carcass of the fourth nestling was removed by 03:58. 


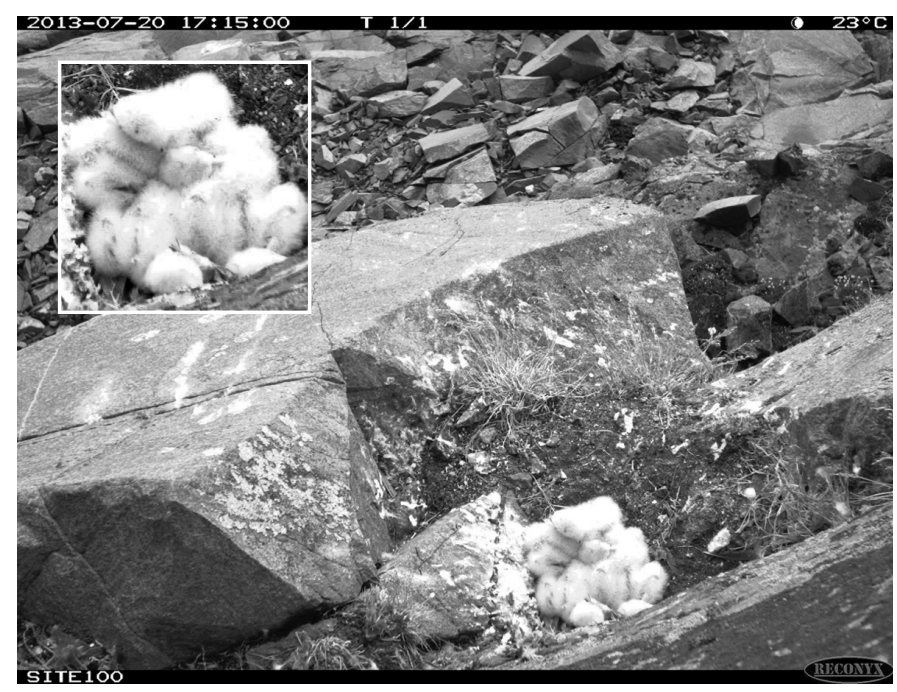

FIG. 1. A brood of four Peregrine Falcon nestlings at a regularly monitored breeding site at Rankin Inlet, Nunavut, Canada on 20 July 2013. Before the black fly attack, all nestlings appeared normal. They were brooded consistently, were fed six times in the 12 hours prior to the appearance of black flies, and responded in a manner consistent with normal feeding behavior (huddled together, sitting upright, actively soliciting and facing the female). Between feeding bouts, the nestlings were active on the nest ledge. A few $(<10)$ black flies were first observed on the nestlings at 17:15.

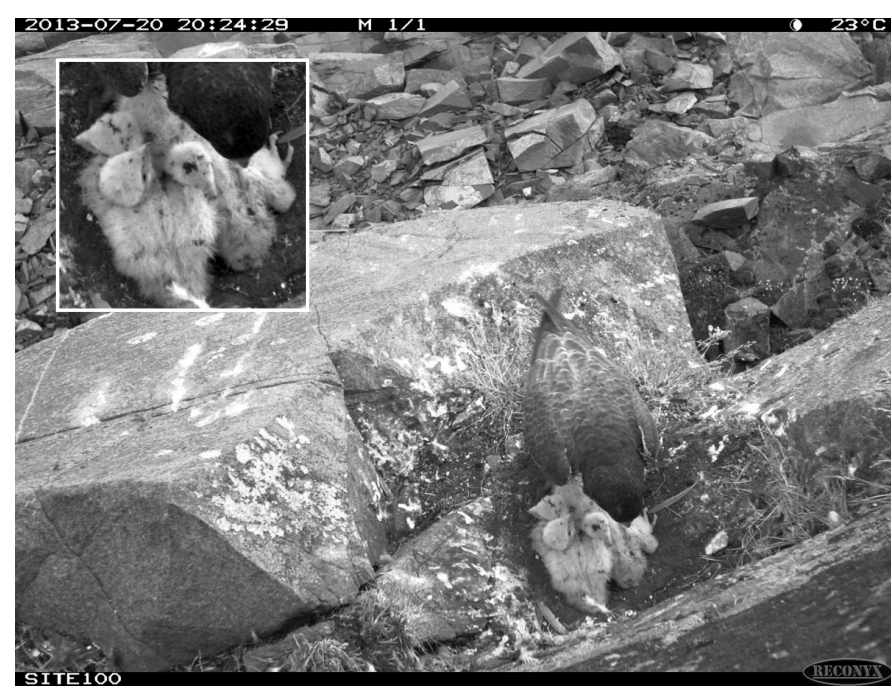

FIG. 2. The four Peregrine Falcon nestlings at Rankin Inlet, Nunavut, on 20 July 2013. Clusters of black flies can be seen on top of the head of each nestling, and it is likely that flies were also buried within the down and swarming about the nestlings. Two nestlings showed hemorrhagic lesions on the crown of their heads by 20:24.

Images from cameras stationed at nine additional sites indicated that broods at eight other sites suffered the effects of biting black flies in 2013. In total, six broods from 10 sites were reduced partially or completely, resulting in the death of 13 of 35 nestlings. A similar, but less pronounced, outbreak occurred on 25 July 2012 and resulted in the deaths of seven nestlings at four sites. No photographic evidence of black flies feeding on nestlings was found in any other year in which motion-sensitive cameras were used to monitor nest sites (2007-15), and no reports of mortality associated with biting black flies were documented for the

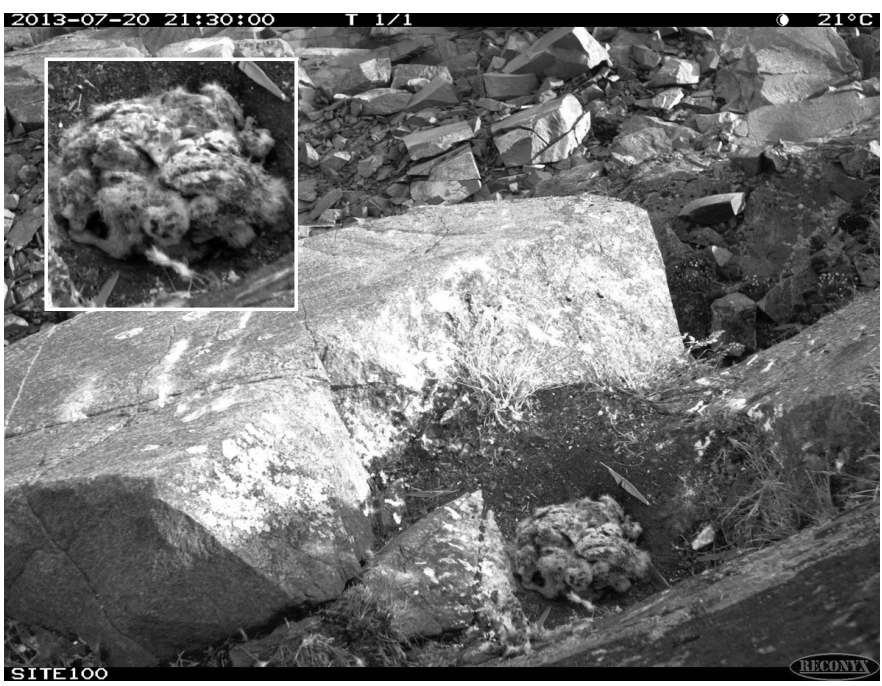

FIG. 3. The four Peregrine Falcon nestlings at Rankin Inlet, Nunavut, on 20 July 2013. By 21:30 the hemorrhagic lesions had coalesced. The attack was most intense over approximately 90 minutes between 20:00 and 21:30, during which the nestlings transitioned from appearing normal (see Fig. 1) to exhibiting body-wide hemorrhagic lesions.

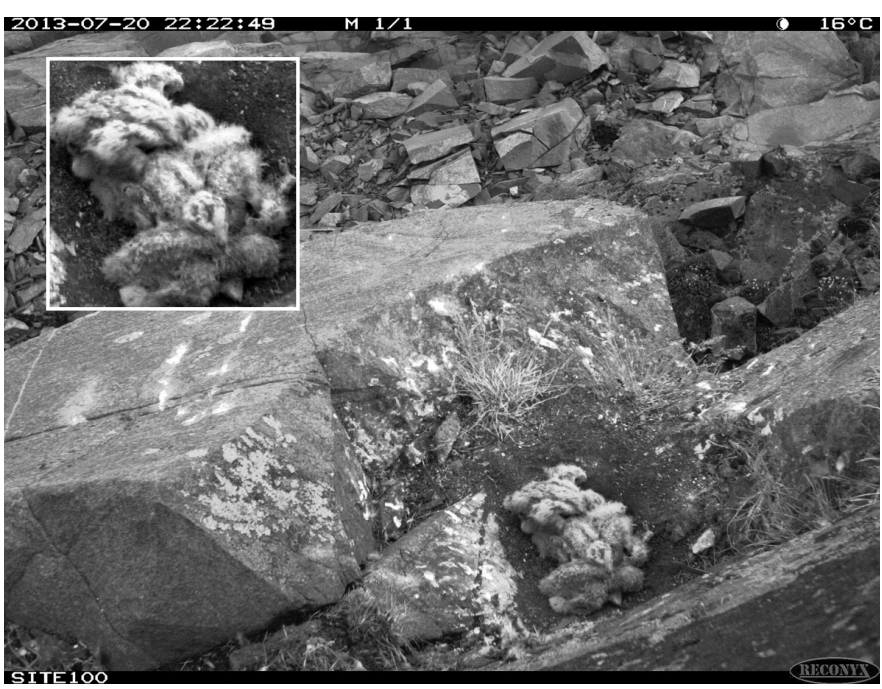

FIG. 4. The four Peregrine Falcon nestlings at Rankin Inlet, Nunavut, on 20 July 2013. The camera switched to infrared mode at approximately 22:22 and the nestlings, although still alive, remained prostrate, with closed eyes, and motionless for long periods.

period from 1982 through 2006. Although we were unable to collect blood-engorged black fly specimens because of the short-lived and unpredictable nature of the outbreak, non-engorged specimens collected in 2013 were identified by D.C. Currie (Senior Curator of Entomology, Royal Ontario Museum) as Metacnephia saskatchewana, an ornithophilic black fly species not previously known to occur in the Rankin Inlet area (Adler et al., 2004).

\section{DISCUSSION}

Studies that showed black flies to have had negative effects on raptor nestlings took place in areas where the 
distributions of raptors and flies typically were known to overlap spatially and temporally, and in those cases, black flies were present and abundant at the time nestlings hatched (Smith et al., 1998). Solheim et al. (2013) suggested that black fly feeding on Snowy Owls may have been associated with selection of atypical nesting habitat in the low alpine zone (lower altitude and greater abundance of kneehigh dwarf birches, Betula nana) by pairs of owls that initiated breeding because of exceptionally high populations of Norwegian lemmings. These explanations are not consistent with the case reported here, as the presence of black flies throughout the chick-rearing period is not typical, and the affected sites are known to be regularly occupied and productive (i.e., not in marginal habitat). This observation is distinguished from other accounts because the events were recorded in real time and documented the intensity of feeding that led to total brood loss over a very short period.

Adler et al. (2004) reported the presence of Simulium silvestre, an ornithophilic species, at Rankin Inlet, as well as other ornithophilic species (e.g., Simulium anatinum and $S$. annulus) near Arviat and Baker Lake, Nunavut. Furthermore, Shewell (1957) reported on ornithophilic black flies collected from other Kivalliq communities relatively close to Rankin Inlet (Arviat, Padlei, Chesterfield Inlet, and Baker Lake) during the 1947-62 Northern Insect Survey. While there is little evidence to suggest that climate change is a contributing factor, Arctic temperatures have risen at almost twice the global rate over the past century, and continued warming is predicted for the near future (Larsen et al., 2014). These patterns are consistent with observations recorded in our study area; over the last three decades, average summer temperature in the region has increased by about $1.5^{\circ} \mathrm{C}$ (Franke et al., 2010), and the frequency of heavy rainfall has increased over the same period (Anctil et al., 2014). It is thus possible that the outbreak of black flies described here signals a climaterelated range shift similar to those documented for other wild animals and plants (Hersteinsson and MacDonald, 1992; Root et al., 2003), as well as for insects (Parmesan, 2006). However, it is also possible that this outbreak may simply have been a normal, but rarely occurring, event resulting from a combination of weather conditions (temperature and precipitation) that provided ideal circumstances for the reproduction of adult flies during the previous summer. Regardless, this observation contributes to a growing body of evidence suggesting that black flies can play an important role in the nesting success of avian species. Observations such as these are rare and difficult to acquire; ongoing annual monitoring, using a combination of repeated site visits, motion-sensitive cameras, and insect collection, will be required to determine whether hematophagous black flies are to become a regular and frequently occurring challenge for Peregrine Falcons and other avian species raising altricial young in the Arctic.

\section{ACKNOWLEDGEMENTS}

This work was funded by ArcticNet, the Department of Environment/Government of Nunavut, Mitacs in partnership with Agnico Eagle Meliadine Mine), the Peregrine Fund, NSERC, FQRNT, NSTP, and C/Bar. We thank Andy Aliyak for his contribution to fieldwork. The help and support received from personnel of the Department of Environment, especially Mitch Campbell, Raymond Mercer, Daniel Kaludjak, and Johanne Coutu-Autut, was essential and much appreciated. We would like to thank Stephane Robert, Phil Roy, and Alex Gauthier of Agnico Eagle Mines for ongoing logistical support, and Agnico Eagle Mines for Mitacs industry partner funding to support field work and student stipends. We express our gratitude to the Board of the Kangiqliniq Hunters and Trappers Organization for their approval and ongoing support for this research project. We are also very grateful to Mike Shouldice and Dorothy Tootoo from the Nunavut Arctic College and to the people of Rankin Inlet. We wish to acknowledge the contribution of three anonymous reviewers, whose comments resulted in a much-improved manuscript. In addition, we thank Doug Currie of the Royal Ontario Museum for species identification of the black flies collected during our fieldwork in 2013.

\section{REFERENCES}

Adler, P.H., Currie, D.C., and Wood, D.M. 2004. The black flies (Simuliidae) of North America. Ithaca, New York: Cornell University Press.

Anctil, A., and Franke, A. 2013. Intraspecific adoption and double nest switching in Peregrine Falcons (Falco peregrinus). Arctic 66(2):222-225.

http://dx.doi.org/10.14430/arctic4294

Anctil, A., Franke, A., and Bêty, J. 2014. Heavy rainfall increases nestling mortality of an Arctic top predator: Experimental evidence and long-term trend in Peregrine Falcons. Oecologia 174(3):1033-1043.

http://dx.doi.org/10.1007/s00442-013-2800-y

Bradley, M., Johnstone, R., Court, G., and Duncan, T. 1997. Influence of weather on breeding success of Peregrine Falcons in the Arctic. The Auk 114(4):786-791.

http://dx.doi.org/10.2307/4089303

Bukaciński, D., and Bukacińska, M. 2000. The impact of mass outbreaks of black flies (Simuliidae) on the parental behaviour and breeding output of colonial Common Gulls (Larus canus). Annales Zoologici Fennici 37(1):43-49.

Court, G.S., Bradley, D.M., Gates, C.C., and Boag, D.A. 1988a. The population biology of Peregrine Falcons in the Keewatin district of the Northwest Territories, Canada. In: Cade, T.J., Enderson, J.H., Thelander, C.G., and White, C.M., eds. Peregrine Falcon populations: Their management and recovery. Boise, Idaho: The Peregrine Fund, Inc. 729-739.

Court, G.S., Gates, C.C., and Boag, D.A. 1988b. Natural history of the Peregrine Falcon in the Keewatin District of the Northwest Territories. Arctic 41(1):17-30.

http://dx.doi.org/10.14430/arctic1688 
Court, G.S., Gates, C.C., Boag, D.A., MacNeil, J.D., Bradley, D.M., Fesser, A.C., Patterson, J.R., Stenhouse, G.B., and Oliphant, L.W. 1990. A toxicological assessment of Peregrine Falcons (Falco peregrinus tundrius) breeding in the Keewatin District of the Northwest Territories, Canada. Canadian FieldNaturalist 104(2):255-272.

Currie, D.C., and Hunter, D.B. 2008. Black flies (Diptera: Simuliidae). In: Atkinson, C.T., Thomas, N.J., and Hunter, D.B., eds. Parasitic diseases of wild birds. Oxford: WileyBlackwell. 537-545.

Doyle, F.I. 2000. Timing of reproduction by Red-tailed Hawks, Northern Goshawks and Great Horned Owls in the Kluane boreal forest of southwestern Yukon. MSc thesis, University of British Columbia, Vancouver, Canada.

Fitch, H.S., Swenson, F., and Tillotson, D.F. 1946. Behavior and food habits of the Red-tailed Hawk. The Condor 48(5):205 - 237. http://dx.doi.org/10.2307/1363939

Franke, A., Setterington, M., Court, G., and Birkholz, D. 2010. Long-term trends of persistent organochlorine pollutants, occupancy and reproductive success in Peregrine Falcons (Falco peregrinus tundrius) breeding near Rankin Inlet, Nunavut, Canada. Arctic 63(4):442-450. http://dx.doi.org/10.14430/arctic3333

Franke, A., Therrien, J.-F., Descamps, S., and Bêty, J. 2011. Climatic conditions during outward migration affect apparent survival of an Arctic top predator, the Peregrine Falcon Falco peregrinus. Journal of Avian Biology 42(6):544-551. http://dx.doi.org/10.1111/j.1600-048X.2011.05466.x

Franke, A., Galipeau, P., and Nikolaiczuk, L. 2013. Brood reduction by infanticide in Peregrine Falcons. Arctic 66(2):226-229. http://dx.doi.org/10.14430/arctic4295

Hersteinsson, P., and MacDonald, D.W. 1992. Interspecific competition and the geographical distribution of red and Arctic foxes Vulpes Vulpes and Alopex lagopus. Oikos 64(3):505-515. http://dx.doi.org/10.2307/3545168

Hunter, D.B., Rohner, C., and Currie, D.C. 1997. Mortality in fledgling Great Horned Owls from black fly hematophaga and leucocytozoonosis. Journal of Wildlife Diseases 33(3):486-491.

http://dx.doi.org/10.7589/0090-3558-33.3.486

Johnstone, R.M., Court, G.S., Fesser, A.C., Bradley, D.M., Oliphant, L.W., and MacNeil, J.D. 1996. Long-term trends and sources of organochlorine contamination in Canadian tundra Peregrine Falcons, Falco peregrinus tundrius. Environmental Pollution 93(2):109-120. http://dx.doi.org/10.1016/0269-7491(96)00037-1
Larsen, J.N., Anisimov, O.A., Constable, A., Hollowed, A.B., Maynard, N., Prestrud, P., Prowse, T.D., and Stone, J.M.R. 2014. Polar regions. In: Barros, V.R., Field, C.B., Dokken, D.J., Mastrandrea, M.D., Mach, K.J., Bilir, T.E., Chatterjee, M., et al., eds. Climate change 2014: Impacts, adaptation, and vulnerability. Part B: Regional aspects. Working Group Contribution to the Fifth Assessment Report of the Intergovernmental Panel on Climate Change. 1567-1612.

L'Hérault, V., Franke, A., Lecomte, N., Alogut, A., and Bêty, J. 2013. Landscape heterogeneity drives intra-population niche variation and reproduction in an Arctic top predator. Ecology and Evolution 3(9):2867-2879.

http://dx.doi.org/10.1002/ece3.675

Parmesan, C. 2006. Ecological and evolutionary responses to recent climate change. Annual Review of Ecology, Evolution, and Systematics 37:637-669. http://dx.doi.org/10.1146/annurev.ecolsys.37.091305.110100

Rohner, C., Krebs, C.J., Hunter, D.B., and Currie, D.C. 2000. Roost site selection of Great Horned Owls in relation to black fly activity: An anti-parasite behavior? The Condor 102(4):950-955.

http://dx.doi.org/10.1650/0010-5422(2000)102[0950:RSSOGH ]2.0.CO;2

Root, T.L., Price, J.T., Hall, K.R., Schneider, S.H., Rosenzweig, C., and Pounds, J.A. 2003. Fingerprints of global warming on wild animals and plants. Nature 421:57-60.

http://dx.doi.org/10.1038/nature01333

Shewell, G.E. 1957. Interim report on distributions of the black flies (Simuliidae) obtained in the Northern Insect Survey. Environmental Protection Technical Report No. 7. Ottawa: Defence Research Board.

Smith, R.N., Cain, S.L., Anderson, S.H., Dunk, J.R., and Williams, E.S. 1998. Blackfly-induced mortality of nestling Red-tailed Hawks. The Auk 115(2):368-375. http://dx.doi.org/10.2307/4089195

Solheim, R., Jacobsen, K.-O., Øien, I.J., Aarvak, T., and Polojärvi, P. 2013. Snowy Owl nest failures caused by blackfly attacks on incubating females. Ornis Norvegica 36:1-5. 